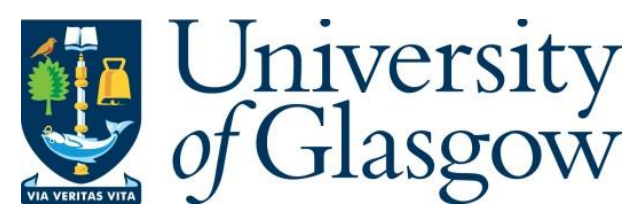

Alawattage, C. and Alsaid, L. A. (2018) Accounting and structural reforms: a case study of Egyptian electricity. Critical Perspectives on Accounting, 50, pp. 15-35.

There may be differences between this version and the published version. You are advised to consult the publisher's version if you wish to cite from it.

http://eprints.gla.ac.uk/194874/

Deposited on: 5 September 2019

Enlighten - Research publications by members of the University of Glasgow

http://eprints.gla.ac.uk 


\title{
Accounting and structural reforms: a case study of Egyptian electricity
}

\author{
Chandana Alawattage ${ }^{1}$ \\ University of Aberdeen, UK \\ Loai Alsaid \\ The Open University, UK, and Beni-Suef University, Egypt.
}

\begin{abstract}
This paper theorizes accounting's role in realizing the state's political ambitions. It triangulates Dillard et al.'s (2004) institutional theory framework with historical institutionalism in order to trace the institutional layers and political processes that connect micro-organizational changes with ideological transformations within the political state. Data comes from an 'extended case study' comprising a three-month fieldwork into an Egyptian electricity company's cost management practices and an extensive review of secondary materials on Egypt's electricitysector reforms. Empirical findings provide insights into the ways in which accounting plays a political role in institutionalizing structural reforms and how that role evolves with the political ideologies of the state. Accounting's political role during the colonial regime was speculation of commercial and scientific gains, while it was signification of centralized political power during the postcolonial military regime. Accounting's role during the neoliberal regime was paradoxical - simultaneously a reformation technology and a deficient institutional apparatus that hindered privatization. Accounting takes political meanings when it institutionalizes the state's reformative ideologies. Accounting makes the connections between the macro-political and microorganizational.
\end{abstract}

Keywords: public sector; new public management; institutional theory; historical institutionalism, Egypt.

\section{Introduction}

Critical accounting research develops through exploring - both theoretically and empirically how accounting relates to macro-political and institutional dynamics. This has been so since its early days in the mid-1970s, when Marxist and Foucauldian accounting researchers started exploring the accounting's political rationalities. Afterwards, notions such as class struggles, politics of production, governmentality, biopolitics, institutional myths and isomorphism, actornetworks, and institutional logics helped conceptualize accounting's social and political connections (e.g., collected papers in Macintosh and Hopper 2005).

This macro-micro connection has been especially important in theorizing accounting changes in less developed countries (LDCs), where large-scale economic enterprises were transformed from colonial to postcolonial and neocolonial forms through nationalization and then structural reforms (see Hopper et al. 2009). Precedent research emphasized exogenous political dynamics in explaining accounting practices in these organizations. They explained how politics of

\footnotetext{
${ }^{1}$ Corresponding author
} 
structural reforms rendered accounting unable to perform the ideal-type techno-economic and rational-bureaucratic role expected of it (see Alawattage et al. 2007; Alawattage and Wickramasinghe 2008; Ashraf and Uddin 2015, 2016; Hopper et al. 2009; How and Alawattage 2012). Attention has primarily been on how politics influences accounting rather than accounting's instrumentality in realizing political ambitions. Our paper, however, focuses on the latter - accounting's role in realizing the state's political ambitions. It triangulates Dillard et al. (2004) institutional theory model (hereafter DetM) with historical institutionalism to trace the institutional layers and political processes that connect accounting changes with ideological transformations within the political state. Data comes from an "extended case study" (Burawoy 1998) comprising a three-month fieldwork into the management accounting practices in the case company and an extensive review of secondary materials on the public-sector reforms in Egypt. We analyze how accounting assumes political meanings when the state uses it to institutionalize its reformative ideologies, showing how accounting makes connections between the macropolitical and micro-organizational.

This paper makes three main contributions. First, it enriches literature that examines connections between accounting and structural reforms in LDCs, demonstrating how accounting intermingles with other political processes to institutionalize macro-political logics. Secondly, it extends institutional theorizations of accounting practices, illustrating how DetM can be triangulated with historical institutionalism to articulate connections between structural reforms and accounting. Finally, using rich empirical data from the Middle Eastern context it demonstrates how accounting helps reconstruct the political state.

The paper proceeds as follows. The next section reviews literature but particularly analyzes accounting's political role in structural reforms. Section three articulates the theoretical propositions of DetM and justifies our triangulation of it with historical institutionalism. Section four explains our methodology. Section five presents the empirical analysis in three main sections: colonial construction of the electricity field; postcolonial nationalization and militarization; and neoliberal transformations. Finally, section six discusses our findings' political and theoretical implications and concludes the paper.

\section{Literature: accounting critique of structural reforms}

Coined by then World Bank President Robert McNamara in 1979, 'structural adjustment' was a lending practice whereby governments received World Bank and IMF loans on condition they implement the lenders' specified economic reforms (Kapur et al. 1997). It subsequently encompassed broader macro- and micro-economic policies and programs but now concerns cluster of overlapping conceptual associations and change programs with specific aims: reconfiguring economies through privatization and managerial modernization of state-owned enterprises; reducing government welfare bills and government debts through budgetary reforms; and improving state-owned economic enterprises' efficiency through market-driven mechanisms of governance and management. At the organizational level, this includes reconstructing public-sector institutions "along lines suggested by the model of 'the commercial enterprise' - the privately-owned firm or company operating in a free market economy" (Keat 1991, 2). 


\subsection{Western experiences}

Accounting implications of structural reforms have interested critical accounting researchers since structural reforms began in the industrial West. This extended to LDCs, providing somewhat different analyses and conclusions: in western contexts accounting played a constitutive role but in LDCs was marginal and ceremonial. The West also has greater diversity in accounting critiques of structural reforms; these accounting critiques fall into three somewhat overlapping themes: (1) explaining accounting's role in privatization; (2) challenging neoliberal claims of privatization; (3) explaining the epistemological politics in privatization.

\subsubsection{Accounting's role}

Ogden's (1995) early paper on UK water privatization explained the transformative capacities of accounting regarding redefining organizational objectives, changing the meanings ascribed to organizational processes and activities, and reshaping managerial and political perceptions about what the critical issues are. Through its vocabulary of costs, accounting helped construct new organizational purposes and new internal operational measures of performance and management accountability. Ogden's (1997) subsequent paper on water privatization drew on Miller and Rose's (1990) analysis of governmentality and governing public life to theorize how new accounting and accountability forms were instrumental in regulating the notion of the customer and customer service. Here, accounting's political role involved offering technologies of government through service indicators, especially in constructing an accounting-based calculative regime of customer service. Collectively, Ogden's papers revealed accounting's instrumental role in propagating the neoliberal political proposition that structural reforms through privatization benefit the political masses, who are then transformed into customers of the economic enterprises operating within enterprise cultures (see also Keat and Abercrombie 1991).

Skaerbaek and Melander's (2004) field study on strategy translation in a Danish governmentowned company under privatization drew on the sociology of translation (Callon 1986; Callon and Latour 1981) to demonstrate how accounting was evident in various forms and how accounting during translation processes changes characteristics and uses from principles of control to principles of financialization. Intermingled with New Public Management (NPM) ideologies and technologies, accounting played a mixed role in translating the organizational form from public to private. While it played a significant role in constructing the new strategy, as a principle of control instigators deemed accounting an obstacle to strategy as it was bureaucratic and unable to act and develop. Symbolic actions to 'get rid' of accounting as a principle of control were also observed (Skaerbaek and Melander 2004, 39).

\subsubsection{Challenging neoliberal claims}

Political claims of greater efficiency, improved quality, and better value for taxpayers' money through privatization have undergone critical scrutiny in accounting literature. Shaoul's (1997) paper demonstrated how accounting modelling and publicly available corporate data can facilitate political analyses and critiques that can help challenge existing notions and problem definitions. For us, Shaoul's paper provided an excellent example of 'critical financial analysis' one used extensively to critique neoliberal claims of privatization (see below).

Papers by Jupe and his colleagues (Crompton and Jupe 2002, 2003; Jupe 2009b, 2009a, 2012; Jupe and Crompton 2006; Jupe and Funnell 2015) are similar critical financial analyses of 
problems associated with "the flawed concept of fragmenting and privatizing a loss-making rail industry in the interests of British capitalism" (Jupe and Crompton 2006, 1035). For example, scrutinizing regulatory, infrastructural, and capital investments issues and others concerning institutional and market apparatuses, Crompton and Jupe's (2003) paper analyzed how the John Major government's three main political reasons for privatizing railways - increasing efficiency, improving quality, and reducing public subsidy - were never realized. Other papers extended this critical analysis to illustrate how the next governments' subsequent regulatory mechanisms similarly failed to achieve performance targets that the regulatory bodies themselves set. These papers offer a collective political critique:

privatization has been used to transfer wealth from the public to the private sector. The policy of privatization provided new profit sources to replace those lost to British capitalism as a result of its relative decline in the face of globalization, and one quarter of the top 100 UK corporations are the result of privatizing nationalized industries. (Jupe and Crompton 2006, 1062)

\subsubsection{Epistemological politics}

Jupe and Funnell's (2015) paper revisited the UK's rail privatization but from another perspective - epistemic justification of privatization through consultancy. Using a critical financial analysis and drawing on the sociology of translation, they examined the roles of private advisors, especially accounting firms, in "flawed fragmentation" and subsequent rail privatization. They explained privatization's "epistemic politics" and demonstrated how the "processes of purification" (see Latour 1993) occurs through private consulting firms' coproducing consulting outputs with their client - the neoliberal government. Bowman (2015), however, analyzed "the appearances that accounting arrangements create". Amid paradoxical stories of brilliant success in privatizing British railways yet accumulating public liabilities and complex state subsidy arrangements, he scrutinized Network Rail's subsidy regime and exposed how malleable accounting helped construct discursive imaginary comprising favorable trade narratives about privatization's promises and outcomes.

Other epistemological politics were evident in privatization programs. For example, McCartney and Stittle (2006) examined how the UK government's non-disclosure of fiscal obligations towards the privatized railway network created illusions of divesting state fiscal obligations. The same authors (2012) also revealed how peculiar contractual terms between the government and privatized entities misplaced risk and return relations to create dysfunctional market conditions, thereby creating far greater government subsidy than British Rail required before privatization. Recently, accounting researchers' critical attention concerned 'accounting manipulations' that suited managers in the privatized industry (see also Jacobs 2009; McCartney and Stittle 2015).

This sample of literature offers accounting critiques on privatization. In various ways, they all show accounting's political roles in justifying neoliberal agenda of structural reforms.

Nevertheless, they also identify the possibilities 'critical financial analyses' offer in constructing alternative narratives to the neoliberal mainstream.

\subsection{LDC experiences}

Accounting critiques of structural reforms within LDCs have taken a different trajectory, perhaps understandably with their roots being in certain UK PhDs in the early 1990s that 
embraced a cultural-political economy approach (e.g., Hoque 1993; Uddin 1997; Wickramasinghe 1996). Influenced by the 1980 s and 1990s critical accounting research developments around the labor process debate, these researchers explored the cultural-political dynamics of control practices in large corporations within LDCs. Such corporations, incidentally, were state-owned enterprises undergoing structural transformations under the advocacy of World Bank, IMF, and Asian Development Bank. Their research characteristically generated field data through interviews, field observations, and other primary data sources. Their analytical focus concerned interconnections between micro-organizational practices and macro-political processes and structures that make accounting in LDCs idiosyncratic. Accordingly, the analyses were not about how accounting implicated the structural adjustments but how structural adjustments marked an episode in the neocolonial evolution of accounting and control systems (see Hopper et al. 2009). The connection between accounting and structural reforms was that structural adjustments were historically specific political-economic phenomena that shaped the case companies' accounting and control practices.

Another important aspect of accounting critiques of structural adjustment programs in LDCs was the inevitable appearance of postcoloniality, center-periphery dialectics, and development discourses. Contrasting western experiences, where structural contradictions existed between public accountability and welfare and private ownership and profits, LDC critiques prioritized contradictions between the global and local. As such, LDC narratives of structural reforms address the neoliberal expansion of market logic to public-sector organizations and World Bank's global hegemony. Accordingly, we identify two main themes of accounting critiques on structural adjustments in LDCs: those contextualizing accounting within structural adjustments and those critiquing World Bank hegemony.

\subsubsection{Contextualizing accounting}

In critical accounting analyses within LDCs, accounting has been deemed the influenced rather than the influencer. This perspective has explored how the political conditions pertaining to structural adjustments render accounting and management control an 'economically ineffective' cultural-political phenomena rather than merely computational processes for rationalizing managerial decision-making. Analytically, therefore, such research is driven by analytical duality between the political-cultural realities of accounting within research sites and an 'ideal-type' (Weber 1968) accounting image derived from western discourses of accounting. Hoque and Hopper $(1994,24)$, for example, explain how

the formal design of accounting and accountability systems, which on the surface were textbook models of rational resource allocation and hierarchical accountability, had been reduced to ritualistic and institutionalized roles within the mills with the gaining of external legitimacy being their primary purpose. Such policies, coupled to political interventions, rendered the accounting and accountability systems ineffective for managers involved in operational decisions and control.

Structural adjustment programs were deemed a particular politico-historical episode that permeated cultural-politics in formal organizational control systems. As such, privatization brought a peculiar combination of political and managerial rationalities, on which critical researchers focused. Uddin and Hopper's (2001) case study of a privatized soap manufacturing company, for example, explored issues pertaining to how political parties and their trade union 
wings complicated the accounting control at the point of production. Drawing on Burawoy's $(1979,1985)$ "manufacturing consent" and "politics of production", they argued that control regimes evolve from colonial despotism to market despotism through structural readjustments that infuse state politics with the politics of production. Accounting's role here involves reproducing the consent and coercion necessitated by the politics such structural readjustments generated. Wickramasinghe et al. (2004) reported on Sri Lankan Telecom privatization to Japanese investors, where hopes were for not only Japanese capital but also such work ethics and culture for company restructuring. However, the "regulatory capture" in this transformation process by political forces, especially the dominant political parties' trade union wings, limited this. Alawattage and Wickramasinghe's (2008) Sri Lankan plantation case study also weaved a similar political narrative but with additional parameters of ethnic politics and civil society involvement.

Extending this theme beyond South Asia did more than reinforce how political parties, trade unions, and other political elites rendered accounting's potential regulatory and control functions impotent. Sharma and Lawrence's Fijian studies (2005, 2015), for example, exemplified the tensions structural adjustments brought into managerial spheres, especially between NPM's profit-driven neoliberal ideology apparatuses and local needs for meeting public welfare. Their 2005 case study of Fiji's Public Rental Board explicated this tension, but their recent study (2015) of Fijian Telecom privatization furthered this from a different angle. Drawing on Habermas's theory of "social development", they demonstrated how wrapping privatization up in convenient managerial and political rhetoric of greater efficiency, effectiveness, and consumer awareness helps political elites make political and economic gains, where propositions of corruption, crony capitalism, and patrimonialism also emerged (see also Lassou and Hopper 2016).

\subsubsection{Critiquing World Bank hegemony}

Critical accounting research deemed structural reforms a hegemonic imposition by the World Bank and other transnational organizations. Researchers focused on such transnational organizations' institutional, epistemic, and economic power to impose managerial practices and ideologies. For example, Neu et al. (2002), using Bourdieu's notions of field and capital, explained how different modes of capital and the "coordinating agency" that the World Bank held as a powerful development funding organization helped impose such structural reforms. Annisette (2004) further argued that the World Bank's hegemony on structural reforms stemmed from the very capitalistic institutions of profit-motive embedded in its ideological, structural, and operational constitution. Developmental benefits from accounting reforms were expected because modernizing accounting practices was supposedly essential for enhancing market efficiency and improving the efficacy of organizational controls. Therefore, structural reforms instigators envisaged massive investments in restructuring LDCs' accounting systems, including the harmonization of accounting standards and development of accounting education as a conditionality of structural adjustment loans (see Annisette 2004; Saravanamuthu 2004; Uddin and Hopper 2003).

Such investments' organizational and managerial efficacy have been central to accounting research. Uddin and Hopper's (2001) Bangladeshi Soap Opera revealed that the accounting changes the World Bank's structural reforms introduced did not bring greater external accountability and transparency. Instead, accounting degenerated into a private bookkeeping 
system whereby private owners could "treat external accounting regulation with impunity" (Uddin and Hopper 2001, 670). The anticipated modernization of management control into a more performance-driven, market-based system never happened; in fact, the resultant harsh regime of coercive control resembled despotic private capital. Uddin and Hopper (2003) tested the World Bank's claims of efficient structural reforms further by comparatively assessing financial and non-financial developmental performance. They questioned the World Bank's narrow criteria (i.e., profitability) at the neglect of more socially and politically relevant issues such as employment conditions, trade unions and individual rights, social returns, financial transparency, and accountability to external constituents. Other accounting researchers have extended this critical assessment of the World Bank's structural reforms and technical assistance programs by analyzing their political and social implications (e.g., Babb 2005; Cooke 2004; Neu and Gomez 2006; Neu et al. 2006; Neu et al. 2002).

Though drawing on diverse empirical materials and theoretical perspectives, accounting research on structural reforms within LDCs reinforced overarching observations:

1. Rather than accounting being understood as a technological instrument to program, facilitate, and legitimate structural adjustment programs, structural reforms were understood as a macro-political event that brought 'new' accounting regimes.

2. In structural reforms' ideal-type scenarios, accounting was an institutional prerequisite to implement neoliberal market logic effectively, as far as accounting would constitute a market-driven performance reporting regime. The World Bank emphasized this by investing in 'accounting infrastructure' developments, including accounting education and homogenizing accounting standards. With such expectations for modernizing accounting practices, various 'informing technologies' were installed through lending agreements as conditions for loans (Neu et al. 2006).

3. However, instead of bringing broader developmental outcomes, such restructuring brought private accounting and control with widespread degeneration of employment conditions and public accountability. Nevertheless, the World Bank hegemony on structural reforms operated discursively, legitimizing the reforms through narrow profitdriven performance measurements, though the dubious accuracy of accounting information on which such claims were made proved problematic.

This paper extends these critical insights by explaining how accounting intermingles with other historical and political processes to institutionalize higher order political principles such as militarized nationalism and neoliberalism. It illustrates how accounting changes are integral to institutionalizing the political state's changing ideologies.

\section{Theory: institutionalism, accounting, and structural reforms}

To the extent it constitutes "an established order comprising rule-bounded and standardized social practices" (Dillard et al. 2004, 508), accounting is an institutional element and is both legitimated and legitimizing. For a form or regime of accounting to prevail legitimately, it must encompass and represent the socio-political and economic rationalities the social system embraces. For example, in industrialized western societies, accounting should encompass and represent the institutional logic of economic efficiency, often articulated as capital accumulation. As our empirical analysis will show, in a nationalistic military regime in Egypt, accounting 
encompassed a different political logic to facilitate the centralization of power. However, accounting is also a conscious effort by the organization - or a hegemonic, coercive, or discursive imposition on the organization by an external party such as political state, World Bank, or other regulator - to create, maintain, and manage legitimacy in the eyes of external constituent groups to receive their continued support (Dillard et al. 2004; DiMaggio and Powell 1983; Meyer and Rowan 1977; Tolbert and Zucker 1983).

\subsection{Micro-organizational institutional processes}

Institutional analyses of accounting changes broadly have two theoretical approaches. The first extends an attempt to merge old institutional economics and structuration theory (Barley and Tolbert 1997) and concerns the intra-organizational approach Burns and Scapens popularized (Burns 2000; Burns and Scapens 2000). Their recursive framework located accounting change between agential action and the organizational-level institutions (i.e., rules and routines) that structure such action. In its institutionalized form, accounting involves "taken-for-granted ways of thinking and doing in a particular organization" (Burns and Scapens 2000, 5). Its change happens through interplaying institutions and social actions - specifically the agential actions of encoding, enacting, reproducing, and institutionalizing - and this gives organizational actors the agential capacity to change institutions over time. Analyzing accounting change therefore addresses how social actors in organizational settings encode, enact, reproduce, and institutionalize particular rules and routines that social actors identify as accounting. The resulting analysis hence signifies social agency in actions that comply with (rather than overtly antagonize and resist) rules and routines. Changes in accounting rules and routines come from social actors finding such compliance difficult because 'exceptions' inevitably emerge over time.

Their theoretical framework conceptualizes accounting as sedimentary processes of day-to-day organizational life and explains how accounting change happens through mundane 'encounters' between the transactions and events that existing rules and routines cannot totally rationalize (e.g., Börner and Verstegen 2013; Guerreiro et al. 2006; Johansson and Baldvinsdottir 2003). However, as Burns and Scapens (2000, 4-5) explicitly state, it omits links between organizational practices and institutional dynamics beyond organizational boundaries. This micro-organizational emphasis prevents the analysis from relating organizational practices to the broader social, economic, and political contexts within which they are grounded and, at times, imposed (Dillard et al. 2004, 511).

\subsection{Connecting micro-organizational with macro-political}

The second approach, broadly, explores how accounting changes relate to exogenous environmental factors and structures, constituting a wide array of institutional analyses to include new institutional sociology, historical institutionalism, new institutional economics, and institutional logic perspectives. However, we prioritize DetM for two reasons: first, because it focuses on the recursive interactions among organizational, field, and political dynamics; and secondly, to capture the theoretical themes emanating from our data, it can be effectively triangulated with historical institutionalism. As we explain below, we see no fundamental epistemological or ontological conflicts between them that would prevent their eclectic use with our data. 
Synthesizing ideas of Weber (1958, 1968), Clegg (1989), DiMaggio and Powell (1983), and Barley and Tolbert (1997) as well as Giddens' (1984) structuration theory, DetM articulates "continual, dynamic change and the significant influence of historical, social and political factors in the institutionalization, transposition and deinstitutionalization of accounting practices" (Dillard et al. 2004, 512). It envisions institutionalization as proceeding in a recursively cascading manner in three levels.

1. The macro level represents the overarching political, economic, and social systems that establish and disseminate norms and values to society members (Dillard et al. 2004, 512). While acknowledging possibilities of institutions being created and modified bottom up, it recognizes a top-down hierarchy of institutional influence. As such, the economic and political level provides the most general and overarching political normativity according to which political power is distributed. This is manifested in the way the political-economic system is institutionalized. For example, market capitalism is such a political-economic system and its political normativity is manifested in private property rights, quest for capital accumulation, investor primacy, and the centrality of markets. This overarching normativity is then articulated through what Dillard et al. (2004) call "sense-making criteria". These, for example, include security laws and accounting standards that support private property rights, capital accumulation, and shareholder primacy; financial statements provide calculative representations of them.

2. The organizational fields level includes socio-economic configurations such as industry groups, professional institutes, and geographical collectives. A field is a distinctive domain of social actions where "sense-making criteria" emanating from the 'political-economic system' are understood, interpreted, and deployed according to idiosyncrasies of that domain of activities. Dillard et al. (2004, 513-514) argue that operating practices considered legitimate at the organizational field level derive from "organizational field criteria" and provide the legitimating and regulative base for actions at the organizational level.

3. At the organizational level, individual organizations inhabit fields and institutionalized practices cascading from the political economic level through the field level are 'adopted' by individual firms either as early adopters and innovators or late adopters. At this level, Dillard et al. suggest that integrating Burns and Scapens' ideas into the framework could show how rules and routines become institutionalized through the micro-organizational actions of encoding, enacting, reproducing, and institutionalizing. These agential actions then revert hierarchical institutionalization processes across the three levels by modifying and reinventing the norms, rules, and routines.

\subsection{Conceptualizing accounting change}

The DetM articulates the cascading flow of institutional influences from political-economic to organizational levels and vice versa. Accordingly, the changes in accounting practices are envisaged through this cascading flow of institutional influences; and the impetus for such changes emanates from the tensions between symbolic representation (i.e., signification), rationality (i.e., legitimation) and power (i.e., domination). This conception locates accounting change within the dialectics between the agency and structure where the change emanates from the way in which the knowledgeable, reflexive social agents enact the processes of institutionalizing, embedding, and deinstitutionalizing the structures of signification, legitimation, 
and domination. Hence, "the possibilities for change are implicit within the processes of structuration. As agents instantiate the structures through their actions, evolutionary changes may occur." (Dillard et al, 2004, 534). Such changes brought about through the structure-agency duality would challenge the status quo and hence can constitute "radical changes" as well.

However, when we mobilize DetM to theorize episodic changes of accounting regimes due to 'exogenous political events' (as in our empirical case), there is a necessity to capture the way in which such socio-political categories and events as political elites, political parties, military actions, economic crises, international development funding agencies, and their reform programs etc. create overarching institutional changes spanning from radical shifts in the political ideologies and political regimes to changes in micro organizational policies and practices. They are the socio-political elements through which ideological signification, legitimation, and domination take place. While such categories manifest structures of signification, legitimation, and domination, an explicit theoretical treatment of them is necessary to maintain the political embeddedness and richness of the empirical and historical narratives. Such events and categories often appear in the field data very strongly when social agents reveal their lived experiences of change. Especially with episodic changes of a public-sector utility in a postcolonial context, the political and historical become intertwined to form complex 'politico-historical circumstances'. Manifesting political struggles of the time, these 'politico-historical circumstances' function as the ideologically driven 'social movements" that trigger reforms across the structural triad of polity, society, and economy. They often emerge and evolve as antitheses to the political systems' dysfunctional elements that need overthrowing or reforming. Postcolonialism, nationalism, socialism, liberalism, and neoliberalism are such politico-historical 'movements' (cf. capitalism and communism as political 'systems' in Dillard et al (2004)) that reform interconnections between polity, economy, and society but historically and geographically specific manner.

Supplementing DetM with historical institutionalism helps us integrate such 'politico-historical circumstances' into the analysis and, thereby, to offer the "specificity" that Dillard et al (2004, 534) call for. Historical institutionalism draws on Marx's historical materialism and Weber's comparative institutional theory (see Campbell 1997). It provides a useful framework for analyzing institutional properties that emanate from politico-historical movements and for articulating how social structures evolve in response to politico-historical circumstance, and even for exploring how those structures constrain and enable human actions (Campbell 1997; Immergut 1998, 2006; Lecours 2000; Skocpol 1995).

Historical institutionalism holds that historically contingent socio-political struggles shape 'institutional capacities' and 'opportunity structures' with which social agents perceive and explore the distribution of political power. As such, historical institutionalists conceive history as a form of political theory that explains how institutions come into being and change. Their analytical emphasis is on historical contingencies and irregularities (Immergut 1998, 2006; Lecours 2000). They emphasize that institutional outcomes are path dependent and reproduced by historically specific and contingent political circumstances. Once institutions are created, they

\footnotetext{
2 The notion of radical change is implicit in DetM. An example of radical change that Dillard et al (2004) provide is the fall of communism in Central Eastern Europe.

3 Drawing on Zald (2000), we conceptualise 'social movements' as ideologically structured actions that can be mobilized in organizations, challenging their formal routines and actions".
} 
would persist on their own and may generate processes unforeseen by actors associated with creating those institutions (see Alawattage and Wickramasinghe 2009; Lecours 2000).

Distributive dimensions of power such as political party systems and structures, electoral rules and procedures, and constitutional provisions are central to institutions' historical construction. Accordingly, as Skocpol (1995, 105; see also Alawattage and Wickramasinghe 2009) argues, institutional analyses must pay attention to the following: (1) the establishment and transformation of the political institutions through which politicians pursue their political interests; (2) the effects of political institutions and procedures on micro-economic enterprises and on the goals and capacities of social groups associated with them; (3) the conflicts between the goals, capacities, and actions of various politically and economically active groups, and the historically changing points of access and leverage a nation's political institutions allow; and (4) the ways previously established social policies and institutions affect subsequent policies and institutions over time. Making the theoretical connection between DetM's structuration and historical institutionalism, these historical processes then culminate into what we may call a double articulation of the 'political economy of pleasure and desire' (i.e., ideological signification of normative goals of progression, development, capital accumulation, etc.) and the 'political economy of discourse, domination and power' (i.e., legitimation and domination structures through which power is exercised for the normativity emanating from the political economy of pleasure and desire).

Changing political ideologies are integral to institutions' historical construction. At their most abstract and cultural, institutional reforms are ideological and manifest how new political ideologies are promoted as "higher order principles" (Boltanski and Thévenot 2006). They are the political principles towards which institutional reforms are directed. For example, anticolonialism, nationalism, liberalism, and neoliberalism brings in such higher order principles; these doctrines define the new institutional orders political actors envisaged within or out with organizational boundaries. They become "institutional logics" when translated into material practices and symbolic systems including assumptions, values, and beliefs by which individuals and organizations provide meaning to their daily activity, organize time and space, and reproduce their lives and experiences (Thornton and Ocasio 2008; Thornton et al. 2012).

Triangulating DetM with historical institutionalism develops links between the political state's ideological evolution and how those changing political ideologies are encountered and reflected in organizational-level accounting and control practices. Our analysis is underlined by a basic proposition of historical materialism: social institutions evolve through solutions to historically specific political crises (i.e., 'historical and political circumstances'). This evolution then can be understood in terms of the changes in the realms of 'political' and 'politics'. Differentiating between the political and politics is important here. The political concerns the ontological dimensions of social antagonisms (e.g., class antagonisms and antagonisms between economy, society and polity) while politics constitute the institutions and practices that seek to organize human coexistence amid such ontologically fundamental antagonisms and contradictions (Laclau and Mouffe 1985; Mouffe 2005, 2013). For NIS, the connection between these is institutional. NIS primarily focus on the 'politics' - the institutional apparatuses through which human coexistence is organized in and between micro and macro realms according to certain political criteria, norms, rules, and routines. However, the fundamental social antagonisms behind the 
historical evolution of such political criteria have received little attention in such institutional analyses, which reinforces the need for triangulating NIS with other historical and political modes of analysis (see Hopper and Major 2007). Augmenting DetM with historical institutionalism provides us the analytical capacity to surpass this NIS limitation and thus see how 'the political' evolves (or stays the same) over time, (but) creating different institutionalized accountability relations, rationalities, and practices (i.e., politics).

There is a possibility that politics would evolve without fundamental shifts in their ontological conditions (i.e. political), especially in the distribution of political power across economy, society and polity (see Laclau and Mouffe 1985; Mouffe 2005, 2013). This means that, in DetM terms, there is a possibility that structures of signification and legitimation can change but without a fundamental change in the structures of domination in their 'ontological terms', perhaps, creating a false consciousness of democracy and freedom. Here, 'ontological terms of political' refer to the structural connections between 'political categories' such as polity, economy, society, and classes which determine who colonize and dominate whom. For example, as we will show in our empirical analysis, Egyptian state evolved from a colonial to postcolonial in its 'politics' but holding onto its colonial political apparatuses of a highly centralised and dictatorial political state dominating the economy and society. This dictatorial political state continued even amid the neoliberal discourses and reforms aiming at privileging the economy and civil society with, for example, privatisation and social capital initiatives. Only the political elites controlling the resources (power) changed manifesting regime changes. Consequently, new norms and values and the representational devices/systems (e.g. accounting) were imposed by the changing political elites to impose their will and to legitimate their political power. Management accounting change therefore manifested such institutional 'politics' through which this legitimation was attempted but without a fundamental shift of power from the political state to the social agents operating in the realm of economy or civil society (e.g. professionals, trade unions, labourers etc.). Attention on 'historical and political circumstances' is necessary to capture such possibilities.

\section{Methodology}

In theorizing accounting's role in realizing the state's political ambitions, we need a methodology that can reflexively connect micro-organizational data with historical and ideological transformations within politics. Burawoy's $(1998,2009)$ "extended case method" allows this because, "the extended case method applies reflexive science to ethnography in order to ... move from the 'micro' to the 'macro,' and to connect the present to the past ... all by building on preexisting theory" (Burawoy 1998, 5). This approach relies on fieldwork methods such as interviews, field observations, and archival and other documentary evidences pertaining to micro-organizational processes, relations, and objects. The 'extension' occurs in four interrelated dimensions: extending the observer to the participant; extending observations over space and time; extending out from process to force; and extending theory (Burawoy 1998, 16-22). The 'reflexive science' in these extensions deploys multiple dialogues to reach theoretically and politically meaningful explanations of empirical phenomena. This includes, first, a virtual or real dialogue between the researcher and the researched. Secondly, this first order dialogue must be 
located within a second order dialogue between local and extralocal processes. That dialogue, in turn, can be comprehended only through a third, an expanding dialogue of theory with itself (Burawoy 1998, 5). The first stage dialogue indeed manifests the reflexive data collection strategies while the other two relate to the data coding and interpretations that make macropolitical sense of the micro-organizational data.

\subsection{The site and the access}

The Middle Egypt Electricity Distribution Company (MEEDCO), our case site, is a key Electricity and Energy (E\&E) distribution company in Egypt with 13 branches, 56\% market share, 1.7 billion Egyptian Pounds (approx. 10 million US\$) annual profit, and 8,718 employees (MEEDCO 2013). MEEDCO was selected for two reasons. First, it illustrates Egypt's politicaleconomic transitions, having experienced various structural reforms since its inception during colonial times. Second, it offered rich access for fieldwork. Personal connections with top management helped researchers build trusting relations with participants for meaningful talks and close observations of accounting processes, programs, interactions, and structures. Data quality and credibility could also be enhanced by cross checking them with multiple participants and other available documentary evidences.

In gaining access to the case company, we obtained formal written permission from the Central Agency for Public Mobilization and Statistics (CAPMS) in Egypt. As per Presidential Decree No. 2915 of 1964, CAPMS must authorize data collection from state-owned enterprises. Next, researchers personal contact with the Financial Manager (FM) helped organizing field visits, conducting interviews, obtaining necessary company records and reports, and making nonparticipant observations. During our field visits, we established friendly relations with other staff, which facilitated subsequent inquiries via e-mail, Skype, and telephone calls.

\subsection{Data collection}

Data was collected from two different but interrelated dimensions: the macro-political and field conditions that create exogenous institutional pressures for the company; and the micro, internal reconfiguration of organizational structures, processes, and practices through which such exogenous changes are internalized into durable accounting practices. Most macro data mainly came from secondary published materials (e.g., reports, periodical magazines, local newspapers, journal articles, websites), though interviewees also provided some insightful comments about the macro-political conditions/events. Micro data mainly came through interviews with different organizational actors (e.g., accountants, operational managers, and IT staff) and direct observations of their day-to-day activities. Nevertheless, as we conducted no "participant observations" (in a Burawoyian sense), our data collection strategies are only partial 'extensions' from the observer to participant. Our participation in decision-making and accounts preparation processes was very limited and only went up to the level of interviewees showing us step-by-step how they carry out specific accounting activities.

We triangulated data between interviews, observations, and documentary readings for a more panoramic picture of accounting from different perspectives. The second author made nine separate visits to the head office for the main data collection phase from 15 November 2013 to 15 February 2014. He conducted around five interviews during each visit and spent working days within different operating departments. On his first two field visits the FM accompanied him. 
Overall, 42 formal interviews were conducted with 28 different people: 16 accounting \& finance personnel, seven operational managers and five IT staff. Interviews were tape recorded whenever possible and all recordings were transcribed. They were conducted in either Arabic or English (respondents chose). Interview times ranged from 30 minutes to two hours but most were about one hour. Two joint meetings were conducted: one between the second author, the Marketing Manager, and the FM, the other between the second author, the Cost Department Head, and the IT Manager.

The second author was allocated an office (next to the FM's) for his stay. He spent lunch breaks with the FM and his staff, which involved numerous work-related discussions. He could move freely inside the company, and visiting the on-site library and other information sites contributed greatly to his knowledge of the company. The second author attended eight formal managerial meetings (non-participant - seven corporate level, one departmental), which were not tape recorded though notes were taken. Observing meetings furthered his understandings of management accounting interactions and decision-making, while generic informal observations were continually made throughout his fieldwork.

Company documents provided much company information generally and accounting processes particularly. Also, diverse texts from internal cost sheets and computer screenshots to publicly available documents were collected. While some internal documents could be photocopied and taken, many could be consulted on site. Extensive notes were taken when they could only be consulted. Publicly available documents were collected on site from company archives, the library, and managers' personal collections, and downloaded from the company website, and business-related newspapers. Previous research also provided useful data.

\subsection{Data coding}

The data was analyzed and coded manually for three reasons: expressions can often signify different cultural-political categories according to the context, the overall data analysis required reading and re-reading the interview transcripts and field diary notes while reflecting on secondary materials, and software-based coding removes such human elements of analyses. During the first stage, the second author read the transcripts while listening to their audio recordings for a general overview and 'feel' for the data. In the second stage, transcripts were reread and coded into specific categories emanated from the interplay between data and theory (e.g., intra-organizational cost management practices, field level cost management practices, field level pricing practices, accounting crises/problems that trigger institutional changes) and historical/political episodes (e.g., date pertaining to colonial construction of the field, postcolonial/military regime, and neoliberal transformation, privatization, modernization, and budgetary reforms). Attention was primarily on identifying specific data instances that reveal (a) the nature of the current regime of accountability; (b) the nature of the previous regimes and how social actors make comparisons between them; and (c) specific policy reforms, and constitutional or legislative instances that triggered changes from previous regimes. The third stage of coding was theoretical and historical, with attention being paid to the data instances (of already coded data) that reveal (a) the connections between local and extralocal processes, where the extralocal is identified in terms of field and political-level dynamics; and (b) the politicohistorical circumstances that provided access and leverage for the nation's political institutions to penetrate micro-organizational practices. This involved continually combining literature-based 
interpretations and other comments with empirical data during our analyses, writing, and rewriting.

\section{Analysis: institutional dynamics of structural reforms}

\subsection{Colonial construction of Egypt's electricity field}

Electricity was an inevitable 'engineering necessity' of western modernization, and its late eighteenth century arrival in Egypt manifested a progressive technological transformation from the oil lamp to electric lighting (Gardner 2007). This 'aspirational good' was a material means of expressing the nation's socio-political and technological progress. Nineteenth-century technological advances and subsequent innovations brought about a cultural shift in Egypt's colonial sensibility and desire, in which it was possible to imagine demands for new and improved facilities and amenities (Issawi 1961). This extended to superior forms of artificial lighting - a 'field' with commercial gains for mercantile capitalists. This development helped meet a prerequisite for colonial expansion: articulating colonial power through material and symbolic means of progress and development to justify its occupation and exploitation of the colonized while offering colonial mercantile capitalists opportunities for capital accumulation.

The colonial construction of electricity as an 'institutional field' involved mobilizing both the 'soft power' of discursive rationalizations and calculations and the 'hard power' of imperial rule. Colonial capital was built on mercantile capitalism, where commercial aspirations for profits fused with the empire's political aspirations (see Robins 2006). Hence, as an element of soft power, techno-managerial calculations and rationalizations were necessary for investment desirability, especially in comparison to oil. Electricity, as an emerging field in which commercial gains can be made with the prestige of being industrious, needed to be rationalized in terms of costs, revenues, and profits. The debate regarding the 'comparative costs' of electricity and gas rumbled on throughout the final decades of the nineteenth century as the two industries competed for commercial supremacy (Gardner 2007). Introducing a new lighting technology had antagonized the oil companies, causing significant commercial rivalry between the two industries. These debates were often played out through the trade press: the electrical engineering industry boasted several weekly publications, including The Electrician, The Electrical Engineer, and The Electrical Review, each of which provided forums for discussing all matters concerning electrical engineering, including the economic efficiency of electricity over oil lighting. Each publication also included news and statistics from individual electricity stations, which were rapidly increasing in number. As an example of how 'comparative costs' and economic rationalizations propagated the construction of a new commercial and political field, the following appeared in a weekly electrical engineering trade journal (The Electrician, 7 January 1882, 121, cited in Gardner 2007, 94):

Our contemporaries, the papers devoted to gas interests, are in a somewhat similar plight to the man who has eaten too much lobster for supper - rather crabbed. They evidently desire to veer round, so as to become the organ of electric lighting interests, for their columns are from week to week devoted more largely to the subject. Yet, feeling that the electric light may possibly be a failure, and that it is impolite to be off with the old love before safely on with the new, they never hesitate to question the accuracy of the figures as given for the cost of electric lighting. The statement is however that the [lower] cost of electricity ... is unassailable. 
As the detailed accounting techniques for ascertaining costs of electricity production and distribution at that time remain absent, such discussions often seem speculative (though discursively powerful) rhetoric from "well-educated gentlemen" and "scientists" (see Gardner 2007). Investments in electricity were assured returns on investment financially and as a good cause - a "superior form of lightening" and an 'aspirational good' that symbolized modernization and scientific progression. As such, electricity represented the progressive development of colonial capitalism in Egypt. Even today, in explaining the pros and cons of colonialism in schoolbooks, the introduction of electricity is mentioned to illustrate the 'progressive' nature of colonial rule in Egypt.

This 'soft' power of discursive rationalization was supplemented by the 'hard' power of legislature. Necessary legislative measures were already passed in British parliament, which then effected the development of the electricity industry in Egypt. Pivotal to this expansion was the Electric Lighting Act, or more specifically those of 1882 and 1888. The former was enacted by Royal Assent on 18 August 1882 and enabled intending companies to apply for licenses, or "provisional orders", to lay the electricity cabling under the streets. It thus created a legal monopolistic power to supply electricity and allowed private companies and local authorities to break up the streets for this purpose. To attract necessary capital for the electricity industry, the Act provided a reversionary purchase rule of 21 years. On 1888 the second was passed, which extended this rule to 42 years, making electricity a more attractive field for investors as it expanded the period of monopolistic conditions (Gardner 2007).

This colonial construction of electricity as a distinct institutional field manifests a key theoretical theme that binds our analysis throughout: any 'field' is a double articulation of the 'political economy of pleasure and desire' and the 'political economy of discourse, domination and power'. Both are attributed to material conditions: the production of goods or services - in this case, electricity. In a capitalistic social order (colonial or otherwise), this double articulation is driven towards capital accumulation, which is the overarching 'higher order principle' that defines capitalism. Hence, the field needs to be organized and institutionalized to accumulate and circulate capital before appropriating the surplus it creates. This also means the field must be so rationalized that the capital, which would otherwise flow to competing fields, is attracted to and retained in the field. Techno-managerial discourses that rationalized profit potential and the legislature that ensured monopoly conditions for a sufficient period were the initial institutional apparatuses that created the field. Nevertheless, in an institutionalized world, capital accumulation would not stand on its own in its pure economic form; hence, it is often infused with other socio-cultural and political logics such as progress, modernization, justice, civilization, and so on. A 'field' is therefore a social space in which multiple but often-competing institutional logics are brought together to link material reproduction to socio-political aspirations.

\subsection{Nationalization and militarization of the field}

Our case company, then British Phillips Orient, entered Egypt in 1940 as a leading supplier of electricity and electrical goods. It enjoyed Egypt's colonial monopolistic conditions until the 1952 Revolution, when the Egyptian Revolutionary Army seized control and President Naser became the ruler. The Revolution took the field's double articulation on a different historical path. On this political desire foregrounded 'nationalism' on the political agenda as a 'higher order principle' (Boltanski and Thévenot 2006); towards this, institutional transformations were 
directed. The Revolution created a different political normativity involving radical institutional change in not only electricity's production and distribution but also many other industrial fields across the country. Nationalism became an ontic element of institutional change, creating diverse institutional logics and measures driven towards it.

Politically, nationalism was articulated via far-reaching legislative measures, beginning with dissolving the colonial parliament. Abolishing the monarchy placed sovereignty with the Revolutionary Council, which passed various legislative reforms (e.g., Agrarian Law of September 1952) to dismantle the colonial elites' political power (Farah 2009; Issawi 1961; Osman 2013). Nationalism as a higher order principle encompassed certain 'transformative impetuses'. Institutionally, it signified two interconnected logics: 'public' (vis-à-vis private) and 'local' (vis-à-vis colonial) ownership and control. Hence, nationalism manifested two political struggles: that against the colonial power and that against capitalistic production. Nationalization was the institutional (and economic policy) means of achieving double-edged nationalism. Free Officers of the Revolutionary Council nationalized foreign properties and investments in insurance, electricity, trading, cement, cigarettes, light metals, spinning, and weaving. For greater economic control, nationalization then extended to large companies Egyptians owned such as Bank Misr (the largest Egyptian Bank wholly owned by Egyptians) - an economic cornerstone that owned several industrial companies (Farah 2009; Soliman 1999).

With this broad political agenda, in 1962 electricity generation and distribution was nationalized and restructured into three political authorities: the Electricity Production Authority, the Electricity Distribution Authority, and the Electricity Projects Implementation Authority. Several subsequent institutional changes in administrative structure have maintained the overarching institutional logic of nationalism, public ownership, and state control. In 1965, the General Authority of Electricity replaced these three bodies and became responsible for electricity production, transmission, distribution, and project implementation. In 1976, the Egypt Electricity Authority was formed to monopolize ownership and implementation of electricity generation, transmission, and project development. Two years later, in 1978, seven regional electricity distribution companies were established under the Egypt Electricity Authority's supervision. In 1983, an additional Electrical Power Distribution Authority was created to supervise distribution companies, which then became independent of the Egypt Electricity Authority (see MOEE website - http://www.moee.gov.eg/english new/define.aspx - accessed on 07/02/2017). This integrated political and economic apparatuses into a single governance structure that was not very different from what was then common in the postcolonial Third World, given the global political push towards nationalization and 'embryonic socialism' (see Hopper et al. 2009). However, a key difference between this global trend and the Egyptian state (and other Islamic countries) was that the latter was not only nationalistic but also militarized (see below).

Nevertheless, for Philips-Orient nationalization had been only partial; state could not fully nationalize it, though the political mood demanded full nationalization (Farah 2009; Soliman 1999). The company heavily depended on Philips' technology and the brand name, so a compromise was required. Accordingly, with Nationalization Law no. 118 (1961) Philips became a 50\% public-sector company, trading under MEEDCO. Its electrical products and services still carried the brand name 'Philips' (MEEDCO archives), but this Nasserite policy was to benefit 
from foreign technology and the global brand name while managing and controlling the company.

The Nasserite state was more concerned about control than ownership. As the post-colonial military state's political power was with Naser and his 'Free Officers' but power needed to be wielded across economic institutions, Nasserite took radical and dictatorial actions in militarizing economic enterprises (Farah 2009; Soliman 1999) through military patrimonialism, whereby military officers became top management in state-owned enterprises (including the MEEDCO). President Naser once stated:

[W] hen the 1952 revolution took place, that a group of my colleagues [the Free Officers] helped me, but after the coup succeeded I ... removed those colleagues from the army, ... I distributed them to the government agencies, public-sector companies, to manage them firstly and secondly to preserve the state security. (cited in Zohny 1988, 63)

Military patrimonialism and legal enactments were fundamental in institutionalizing centralized state control, but accounting also played a key role. For example, standardizing and routinizing accounting systems and practices led to 'coercive isomorphism' (DiMaggio and Powell 1983). The main change involved moving from separate arrangements in each company to a Uniform Accounting System, imposed in 1966 on all partially or fully privatized companies (except banks and insurance companies) through the Central Agency for Accountancy (CAA). This also homogenized accounting classifications in the electricity sector to facilitate their inclusion in national accounts. Since then, in legitimizing the political regime, accounting in state-owned enterprises has been driven by national accounting, central planning, and statistical aggregation of economic performance. Standardized periodic reports flowed through state bureaucracy for national-level aggregation, though their use in operational or strategic decisions was very limited (cf., Briston and El-Ashker 1984). Akin to findings elsewhere (see Alawattage and Wickramasinghe 2008; Hopper et al. 2009; Uddin and Hopper 2001, 2003; Wickramasinghe et al. 2004), we found that operational and strategic decisions were dominated by patrimonial political structures and processes rather than accounting calculations, though accounting was useful in rhetorical legitimations of this militarized control. Our respondents who experienced this period recalled the presence of military personnel being more significant than any bureaucratic measure. Their collective understanding was that "everything went on the way that the military leadership wanted to be; it was their political decisions that mattered during the military regime" (a Senior Accountant). Investment decisions, budget allocations, and the hiring and firing of personnel all came from patrimonial connections and political rationales rather than accounting calculations of efficiency or profitability. Accounting appeared not as an element of calculative rationalization in managerial decision-making but as a facet of legitimating patrimonial political actions through aggregate performance reporting. Our respondents' reflections reflected accounting's formality and legitimacy in displaying militarization as bureaucratic administration.

\subsection{Neoliberal transformations}

By the mid-1980s, the Egyptian economy was clearly in crisis. Total external debt stood at \$US49 billion, and the total external debt to GDP ratio had reached 150\%. The budget deficit equaled $20 \%$ of GDP, and the annual inflation rate exceeded 20\% (Westley 1998). The 1991 Gulf War aggravated the crisis. Over a million workers returned to Egypt after the war, which affected 
workers' remittances, while tourism, a major source of foreign exchange, declined significantly (Osman 2013). In response, Egypt turned to the IMF and the World Bank for help, concluding an agreement with the IMF in May 1991 and the World Bank in November 1991. The IMF focused on monetary, fiscal, and exchange rate reforms; the World Bank focused on economic reforms through investments, liberalization, and privatization. The Egyptian government implemented its Economic Reform and Structural Adjustment Program (ERSAP) in April 1991 to improve balance of payments so Egypt could repay its foreign debt, reduce public debt, and reduce inflation. It also involved lifting price controls, reducing government expenditures (including state subsidies), reducing public investments, imposing new taxes (e.g., sales tax), and freezing wage rates. The government was also asked to sell public utilities to liberalize trade and investment (Omran 2004; Sullivan 1990; Youssef 1996).

The 1990s therefore saw failures in nationalization and of state control; instead, it witnessed the neoliberal ideology of privatization and market control as 'higher order principles' to reform the institutional structure. The World Bank's structural reforms went through three distinct but interrelated phases of reforms - privatization, modernization, and budgetary reforms - that involved different institutional episodes and apparatuses.

\subsubsection{Privatization failed: institutionalizing the private phase-1}

Again, legal enactments were crucial for institutional changes. Public Enterprise Law no. 203 (1991) established the legal framework for selling 314 public enterprises earmarked for privatization (four in the electricity sector, including MEEDCO). It spelt out new rules for stateowned enterprises (SOEs), which made them listed companies with profit making as a primary objective. To ensure the neoliberal institutional logic of open market competition, these enterprises received no subsidies (direct or indirect), differential terms or special interest loans. SOEs were affiliated to 'public holding companies' as subsidiaries so their market and profit performances could be monitored. The law also gave SOEs necessary autonomy in decisionmaking regarding company operations (Omran 2004; Youssef 1996).

Although Law no. 203 (1991) laid down the necessary legal conditions for selling 'public enterprises', the institutional framework was incomplete, especially a conductive capital market was in need. To address this, Law no. 95 (1992) enacted primary and secondary capital markets to encourage investment and private savings, and to stimulate the capital market by establishing mutual funds (see Youssef 1996). As of 30 June 2002, of the 314 initially earmarked public enterprises for privatization 189 had been sold through anchor investments, asset sales, sales to employee shareholder associations, asset liquidations, and long-term leases (Omran 2004). Nevertheless, the government's attempt to sell MEEDCO back to Phillips failed because of lacking market criteria of profitability. Consequently, in 1991 MEEDCO was made a subsidiary of the Egyptian Electricity Holding Company (EEHC) - a joint-stock company listed in the stock exchange but fully owned by the Egyptian government (MEEDCO 1998). The explicit aim of this institutional arrangement was to depoliticize the enterprise by transferring ownership to a holding company established for that purpose, a company expected to operate as a private sector organization so that it would be suitable for private investments. In 1997, renegotiations between the Egyptian government and Phillips for full privatization still failed. Inter alia, as our respondents explained, having no proper, reliable accounting system caused this. Accounting was 
needed to assess 'profit potential'. During negotiations, however, various 'accounting irregularities' gained public attention (see below).

Failed privatization attempts seemed both an organizational and a political failure. Organizational failure was ironically manifested through absence of a proper accounting and internal control system. As some respondents reflected, state patrimonialism was internalized in company affairs and triggered a "terrible accounting crisis" (as per one of the Senior Accountants). In 1999, the Disclosure and Transparency Management Team ${ }^{4}$ (DTMT) identified three main categories of various accounting irregularities (see Egyptian Stock Exchange 2000):

1. Revenue irregularities: These included manipulating the timing of revenue recognition, recording non-existent revenue, allowing others to use the firm's funds for buying its own products/services, and reporting revenues at a value greater than transacted values. Beyond mere accounting 'irregularities' were instances of serious fraud, including altering dates and values on source documents.

2. Expenditure irregularities: These included postponing expenditures to subsequent periods, overvaluing period-end inventories, reducing doubtful debts, and non-recording of continual decline in the values of fixed and intangible assets.

3. Irregularities in disclosures in financial statements. These included insufficient disclosure in the Board of Directors' report, insufficient disclosure about transactions with related parties, and manipulating announcements of business results in the press before publishing financial statements.

As some respondents recalled, in April 2000 an Emergency General Assembly was held to discuss the crisis. The General Assembly was responsible for electing the company's executive management while the senior management team was appointed by the EEHC and the MEE. In this assembly, most executive management was sacked and a new executive board appointed. An Executive Director said: "One of the primary objectives of the new executive board was to establish a proper accounting system, as it was very fundamental for rebuilding the public reputation, credibility, and the economic performance of the company." And also, a "significant investment in a proper computerized accounting system" was deemed necessary. The Executive Director further commented on their new accounting system investment:

The company implemented an advanced ERP package in order to achieve this integration [between top management and operational management and between head office and the branches] ... and to avoid the recurrence of such accounting irregularities. We began the ERP implementation in 2001/2002 through the Globus system. ... Upgraded to the advanced Oracle version in 2006 to increase the integration and enhance the efficiency.... The IT department and Advac (the Oracle supplier) are preparing at the moment two upgrades to the existing Oracle system. It is expected that these upgrades will be operational throughout the whole system in 2016. These include adding a new module integrating geographically dispersed inventories in different governorates with the purchase department and the inventory accounts management, and adding a new module to integrate the projects and plans department with the cost department and material management.

\footnotetext{
${ }^{4}$ DTMT was responsible for auditing the financial reports that listed companies provide every quarter.
} 
During the "1999 accounting crisis", accounting was both the problem of and solution to company management politicization in the militarized regime. This crisis was ultimately positive, as "it provided the long-awaited opportunity for changing the way things was happening here" (Executive Director). "It was politics behind everything happened before 1999 and much happened thereafter to minimize the political interferences" (ibid). Our respondents' collective understanding is that certain political interventions continue but are now framed within an acceptable institutional framework so major accounting irregularities/frauds emanating from politics are much less. ${ }^{5}$

Although, all subsequent attempts of MEEDCO's re-privatization were unsuccessful regarding ownership transfer, certain normative, ideological, and cultural apparatuses of private capital are now in place. This, paradoxically, led to the government's decision to buy shares in the British partner and to own the company fully. The political objective has now changed: to make market apparatuses control state enterprises while the state fully owns them. The argument was that 'market control' and 'performance-driven management' are the core of structural reformations not mere ownership transfer. Managerial reforms were directed towards establishing "a private sector enterprise culture in a public-sector organization". The Deputy Director of the Board states:
Although MEEDCO, like others, is one of the state-owned enterprises, it has a culture and mission of the private business sector. It has been transferred from an operational service firm to a more market-oriented one. This is because of the Privatization Program and the Industrial Modernization Program. This transfer has occurred through a decision by the government especially after its failure to privatize the firm in early 1999 ... Since then, MEEDCO has become a 100\% public-sector company, but we manage it as a private sector company.

Despite the failure in transferring ownership to the private sector, clear transformations happened in managerial ideologies, systems, and practices. De-politicization of management structure is evident with the current management saying they enjoy greater managerial freedom than their predecessors. ERP and other accounting technologies constructed an institutional setting' of a 'profit making organization'. However, the welfare objectives of a public utility still hold strongly in managers' cognitions, which are now underlined by understandings that social welfare and development can be better reached through profit-driven managerial approaches and techniques. The newly established management cadre supports this new managerial ideology and order.

\subsubsection{Modernizing management: institutionalizing the private phase 2}

The European Union-Egypt Association initiated a program officially titled Industrial and Technological Modernization Program (respondents say 'Modernization Program') to improve the profitability and efficiency of those SOEs with failed privatization (including MEEDCO). Accordingly, a "streamlined production strategy" was requested to maximize profit. In response, MEEDCO scaled down its manufacturing activities and imported electrical finished products to

\footnotetext{
5 We understand the necessity to treat such claims from our respondents carefully, especially as they are the firm's current management and because our respondents are generally reluctant to say anything controversial. Nevertheless, we take their claims at face value, differentiating our 'academic research' from 'investigative journalism'.
} 
supplement its core business of producing and distributing electricity. This "streamlined production strategy" currently operates only three manufacturing factories: a glass factory, a general lighting and special electric light bulb factory, and a fluorescent tube factory (MEEDCO 2013).

MEEDCO's managerial structure was reorganized into two separate geographic areas to improve management, coordination, and performance evaluation: Northern and Southern. Both regions were integrated into a Central Operating Area Unit (COAU), which supervises and monitors operational performance. The COAU was established in early 2005 as a separate management unit to monitor the operating performance of different regions and branches but also to produce a "quarterly cost report", which it submits to both the MEE and the EEHC.

These strategic and structural reforms derived from the interplay between welfare and profit logics. The company operated in a regulatory tariff structure that compromised between the economy's welfare and development needs and corporate profits. Tariffs were fixed within three main tiers that reflected the purchasing power of the population's income-based segmentation and certain technical aspects of electricity distribution. On the first two levels, MEEDCO's selling price matched their purchase price from power stations (i.e., below overall variable cost). Only the third tier - industrial supplies - brought a positive contribution (i.e. price $>$ variable cost). Profits therefore came from industrial supplies and 'other manufacturing and trading activities'. A Deputy Director added:

We have actually succeeded in that and the company now holds about $57 \%$ of customers in the industrial electricity market segment. MEEDCO makes its profit through selling this third level of 0.5 E.P. per Kilowatt. It is now big enough to compensate for losses across the first two levels ..., along with those achieved by other market activities such as submitting tenders [for big industrial supply projects], the installation of meters, and the production and sale of energy-saving light bulbs. MEEDCO was the first company to provide these types of bulbs in the Egyptian market and we produce, sell, and export them to Arab markets through a large factory in the Middle East. MEEDCO does not only sell electricity; it also depends on other production activities to make a profit and cover losses that it incurs from sales to the first two electricity levels.

ERP relates to this new production strategy and reporting structure. As many respondents claimed, ERP has reshaped the company's administrative and accounting practices and processes, giving a new managerial outlook as managers now identify their tasks through categorizations and processes the ERP package introduced. Although the "new ERP package was implemented as a solution to the 1999 accounting crises" (a Senior Accountant), it has been instrumental in redefining their day-to-day activity profile. Compared with the 'centralization of authority' during the military regime of corporate governance, accounting has now received a new operational purpose: integrating and coordinating distributed and decentralized manufacturing and distribution centers. The Senior Accountant observes:

The implementation of ERP has connected operational activities and processes between two regions and the COAU. Both regions are sending monthly their own trial balances to the COAU. These monthly balances are sent on the 11 th day of 
every month.... The managers in the COAU are auditing and integrating these

balances and are discussing them with the relevant regions and branches.

ERP has also further integrated administrative and accounting transactions between the COAU and senior management. The FM indicated that ERP implementation has helped in producing and sending the quarterly cost report senior management requires. COAU prepares the cost report using the trial balances that different geographical regions send them each month. The Deputy Director of the Board states:

The purpose of preparing these balances is to monitor the monthly expenses of different operating regions and branches. The preparation of the quarterly cost report would reflect the company's real performance and would help senior management make appropriate decisions.

MEEDCO also introduced, as additional system modules to the ERP, a quality management system (QMS) and a customer relationship management (CRM) system. It was subsequently awarded ISO 9002 and ISO 14000 certificates (MEEDCO 2005). According to the Deputy Director,

\footnotetext{
Oracle gave us the necessary information platform to operationalize an effective organizational division for quality. This division includes four key departments: technical inspection, including the general department of technical quality and the power supply quality department; the general department of commercial quality; the general department of financial quality; and the general department of cooperation with the Authority for Electricity Utility Organization and Consumer Protection (AEUOCP).
}

Overall, 'modernized management' is a modular management platform based on a set of ERP modules. Current management and accounting personnel cognize the 'modernization' mainly via computerized accounting, 'streamlined the production strategy', establishing a QMS, and restructuring the organization's reporting structure to facilitate close monitoring of operational costs. Now they mainly, and proudly, see their managerial functionality through the software's functionalities. When we asked how these changes have influenced their own day-to-day tasks and activities, managers immediately explained how they 'now' interact with the 'new computer system' and the various 'new' reports it produces. Those who experienced the old militarized management regime often explained how they were previously directed by the military personnel's commands and directions but now their activities are directed by the reporting protocols the computer system imposes.

\subsubsection{Budgetary reforms: reconnecting politics and signifying cost management 5.3.3.1 Reconnecting politics}

Current neoliberal transformations attempt to reconnect the 'managerially privatized' energy sector to public finance and government budgeting procedures. This has been necessary because the state now fully owns electricity companies and subsidizes some losses from its central budget. The budgetary pressure comes from the government's plans to reduce the budget deficit from $13 \%$ to $10 \%$ and reduce subsidies particularly in the energy sector (which amounts to 
almost $\$ 18$ billion annually) by around 20\% (Arab Republic of Egypt 2012). According to $\mathrm{Mr}$ Chris Jarvis, leader of an IMF mission on structural reforms in Egypt,

The government's fiscal policy will be anchored to placing public debt on a clearly declining path toward more sustainable levels.... The aim is to raise revenue and rationalize spending, to reduce the deficit, and to free up public funds for highpriority spending, such as infrastructure, health and education, and social protection. As indicated in the budget approved by the parliament, the government ... will continue the program begun in 2014 to rationalize energy subsidies. (https://www.imf.org/en/News/Articles/2016/08/11/09/49/pr16375-Egypt-IMFReaches-Staff-Level-Agreement-on-a-Three-Year-US\$12-Billion-Extended-FundFacility) - Accessed on 03/02/2017)

Program and Performance-based Budgeting (PPB) was a key accounting-based reform element in this regard. In 2014, the Egyptian government made a new constitutional commitment to minimum budget allocations for certain sectors as percentages of GNP, including education, health, higher education, and scientific research (4, 3, 2 and $1 \%$ of GNP respectively). This constitutional commitment made improving public expenditure's visibility and controllability a political imperative. Accounting systems' ability to track expenditure in line with the government's Chart of Accounts (CofA), Government Finance Statistics (GFS), and Classification of the Functions of Government (CFG) was thus deemed essential. PPB sought multiplatform synchronization, reporting, and control of public-sector expenditures (cf., Robinson and Last 2009).

According to the MEEDCo's Finance Director, budgetary reforms involve a three-step process for preparing the budget of the government and its related companies. First, a budget committee is established in each governmental unit to prepare current and capital budget proposals.

Secondly, each government unit submits a budget proposal to its related ministry; each ministry consolidates the budget proposals of related government units then submits a consolidated budget proposal to the Ministry of Finance before January 1st each year. The budget proposals from ministries have supporting documents that justify their estimates and any changes therein from the previous year's appropriations. Thirdly, the Ministry of Finance prepares the State Budget Proposal that, after modifications, consolidates all the ministries' proposals. Finally, the Minister of Finance submits the general state budget proposal to the People's Assembly for approval.

Imposing PPB on MEEDCO produced some structural and procedural changes. Structurally, in response to the CAA's instructions a new managerial/governance committee - the Committee of Administrative and Financial Affairs - was institutionalized. This committee ensures that the intra-organizational processes of budgetary accounting and reporting align with policies and measures the MOEE and the EEHC enforce. A senior accountant explained how the company complies with and integrates into this new budgetary regime:

Budget preparation starts with the formation of the budgeting committee [i.e., the Committee of Administrative and Financial Affairs]. There are two departments [which are permanent members of this committee] responsible for the budget proposal: the General Administration for Revenues and the General Administration for Budget and Encumbrances. The first department prepares the estimates of 
electricity sale revenues and monitors collection. These estimates are based on the previous year's estimated revenues, expected growth rate, and prevailing economic conditions in each industrial sector and service sector. These are prepared for each individual commodity and service separately. The second department, the General Administration for Budget and Encumbrances, prepares expenditure estimates and monitoring the spending. Expenditure estimates are prepared using the forms received from the Ministry of Finance at the beginning of each year.

Procedurally, tighter amalgamation with the Uniform Accounting System was required. As a senior manager defined:

The Uniform Accounting System is a group of regulations and instructions that stateowned enterprises must follow ... in recording and classifying the financial operations and in preparing their budgetary statements.

The Uniform Accounting System demands adoption of a particular accounting coding and classification system to comply with the government's classifications in the CofA. As a senior cost accountant explained:

MEEDCO currently uses the same classification of cost centers in the performancebased state budget. ... [He goes through a list in a manual] ... the production centers include regions and branches; the production service centers include regions and some functional central administrations; the marketing service centers include the central administration for customer assistance; the finance and administrative centers include the central administration for the commissioner's affairs and the central administration for financial and administrative affairs, and the capital transaction centers include the central printing department and the central carpentry department ... This new performance-based classification of cost centers reflects the government's coding system in the state budget, especially Chapter 1 and Chapter 2. The expenditures in Chapter 1 and Chapter 2 are directly allocated to these cost centers.

The Uniform Accounting System also demands a "documentary cycle" of, according to a senior accountant, "documents of original entry" and "supplementary documents". The former record financial transactions in journals and ledger accounts (i.e., "books of records"); they include Expenditure Forms (no. 50 Government Account/G.A. and no. 132 G.A.) and Reconciliation Forms (no. 61 G.A. and no. 62 G.A.). The latter are enclosed with the former to provide additional information and further explanations.

A senior accountant said budgetary reforms also introduced new interim budgetary statements. Previously, MEEDCO prepared only the end-of-year accounts to show actual expenditures and revenues for that fiscal year. According to the government budget law's Executive Manual, especially those chapters and articles about implementing the new performance-based budget, MEEDCO must prepare the following interim budgetary statements (see also MEEDCO 2013):

a) A monthly follow-up report on revenues and expenditures. This report outlines the financial position before closing the accounts.

b) A monthly report on revenues and expenditures (form no. 75 G.A.). 
c) A quarterly report on revenues and expenditures (also form no. 75 G.A.). This contains the expenditures, revenues, and balances of the financial accounts for this period and the same figures for the three preceding quarters.

The Head of the Financial Accounts and Budgeting Department ends his discussion about the new budgetary reporting routines with the observation that

based on monthly cost reports, the accounts department prepares both interim and annual budgetary statements. The objective is to determine whether we comply with the budget appropriations and revenues and to indicate whether these appropriations and revenues were obtained and utilized in accordance with legal and contractual requirements ... All these budgetary statements are submitted to the EEHC, the Ministry of Finance, and the CAA.

\subsubsection{Signifying cost management}

Despite all structural reforms aiming at institutionalizing neoliberal logic of managing for profit, electricity in Egypt remains a political good - in not only its state ownership but also the political sensitivity of its availability to and affordability for the public. Accordingly, prices are still decided not on economic grounds but on political reasoning. Electricity pricing processes are not independent organizational practices; instead, firms are organized into a political field wherein the firm, as a single entity, has no significant market discretion of pricing.

Companies can influence this regulatory pricing structure limitedly through what our respondents call the "pricing study". A senior accountant explained that this "pricing study is not an organizational practice but an industry practice". The ministry sets the tariff structure but the companies can collectively ${ }^{6}$ propose changes, which must be justified by a "cost report" that reveals "operational movements" (including cost, production, sales, inventory, and employees). Negotiations regarding tariff structure connect the micro level (company) and the macro level (state) through specific accounting criteria and practices, specifically manifested in an Operational Cost Movement Reports.

The FM states:

Each company must submit a pricing study once they have finished the preparation of their annual budget. The ministry has some specific criteria for giving electricity companies approval of their proposed supply costs and sale prices. Costs and prices must be determined under the policies set by the ministry and the ministerial decree issued by the Prime Minister on electricity pricing and the tariff structure specified by the minister. That has been put into practice since 1 October 2008. If the ministerial committee formed by the minister finds that the pricing study does not comply with these specific pricing decrees and structures, it will reject the proposal.

This lack of managerial prerogative in pricing and the cost report's centrality in negotiations with the regulators made cost management a critical element of managerial strategy. Indeed, the company's main managerial concern has been managing what managers often call "cost movement". According FM, everybody in the organization knows that the company's profit

\footnotetext{
6 Most of these companies are subsidiaries of the EEHC, which operates in specific geographical zones: Cairo, East Delta, Middle Delta (i.e., our case company MEEDCO), West Delta, Upper Egypt.
} 
potential and, hence, employees' incentives and bonuses totally depend on keeping operational costs within limits. According to a senior accountant, "Identifying and controlling the cost movements is our main function. It is perhaps the most important thing we discuss in our management meetings."

"Cost movement" is the variance between recorded cost and the previous period's figures and the budgeted figures. In classical management accounting, this is merely a variance reporting system. However, for our respondents, who have experienced no such system historically in this state-owned enterprise, it signifies a 'new' organizational epistemology 'introduced by the budgetary reforms'. Our respondents have now learnt the significance of this cost calculation for their operational and strategic objectives. "Cost movement" has become the basic calculative logic through which organizational efficiency is now understood and communicated. Cost reports involve 'managing the cost movement' vis-à-vis 'cost reporting for audits and other acts of regulatory compliance', though this compliance aspect remains important in the new regime. The cost department chief recalled the 'old days' that help them appreciate the new:

In the old accounting systems, MEEDCO only prepared costs for internal auditing and then sent them to the holding company for external auditing. Those reports included only basic information about account statements, a statement of account balances, a statement of cost entries and a list of major cost items.

Now, following privatization attempts, modernization, and budgetary reforms, cost management (i.e., analyzing and controlling "cost movement") has institutionalized as a 'routinized calculation'. As the Head of the Cost Accounting Department explained to us,

Each chief of the cost sub-departments [i.e., inventory cost department, purchase cost department, indirect cost centers department, production cost centers] is responsible for controlling daily operational cost movements in their respective 'accounting headings'. For example, the inventory cost department manages daily cost movement within the inventory department through the ERP system. People in the inventory department upload the daily operating movements of receipts and disbursements into the system. They then compare the actual costs of receipts and disbursements with the budget. Daily differences between the budget and the actual are reported to the Inventory Department Head. He then prepares a formal report the Daily Operating Report - indicating the reasons for these differences and justifying the increases in inventory costs.... The same controlling cycle is managed by chiefs of other cost sub-departments.

This role is not confined to senior cost accountants (i.e., chiefs of cost sub-departments) but also performed by the FM and the board directors. The FM adds:

I log into the system and print this report [showing a printed copy of an aggregate report of cost items]. After checking it I keep it in the 'daily movement file'. If I see any significant differences from the budget, I contact the Cost Department chief and the chiefs of relevant operational departments to inquire about these differences.

As the FM explained, this cost-reporting regime expands beyond the company to various other regulatory institutions. The company must submit aggregate quarterly cost movement reports to the EEHC, the AAC, and the General Authority for Capital Markets by the tenth day of the 
month following each quarter. Since the budget reforms, company accountability has evolved into a multi-agency accountability structure, where company management now feels under continual scrutiny from these regulatory agencies. This, as one of the accountants reflects, is to

make sure that the management keep the operational cost under control and to make sure the company is no more a financial burden for the government. It is not simply the periodic financial statements that matter most but the detailed cost movement reports. That is because they are the real reports that show the changes in costs. Cost is what we now have to explain to the people at the top.

This notion of 'financial burden' to the government has strongly registered in managers' minds. Not being so any more was often stated as one of their great achievements recently.

\section{Discussion and conclusions}

This paper has certain political and theoretical implications.

\subsection{Political implications}

This paper provides understandings on structural reforms and accounting's role therein. Previous literature shows how accounting played a 'constitutive role' in privatization (Ogden 1995, 1997; Skaerbaek and Melander 2004), how critical financial analyses challenged neoliberal claims of privatization (Crompton and Jupe 2002, 2003; Jupe 2009b, 2009a, 2012; Jupe and Crompton 2006; Shaoul 1997), and how accounting reshaped epistemological politics in structural reforms (Jupe and Funnell 2015; McCartney and Stittle 2006, 2012, 2015). More specifically, LDCs studies illustrated how structural reforms infused and confused techno-managerial rationalities with the Third World's political idiosyncrasies and consequently rendered accounting incapable of playing its ideal-type techno-managerial functions (Alawattage and Wickramasinghe 2008; Hoque and Hopper 1994; Uddin and Hopper 2001; Wickramasinghe et al. 2004). This paper's analysis extends these prior observations in two distinct ways.

First, it explains how accounting's political role evolved according to the political state's changing ideologies. Our analytical focus on the 'historical junctures' that triggered policy regime changes with significant institutional ramifications offered a historical-institutionalist understanding of changes in accounting's political role. In the colonial phase of initiating electricity as an industrial field, accounting's role was one of 'speculation'. In the historical phase of colonial mercantilism, where the accumulative logic of colonial investments coupled with the liberal political ideologies of scientific progression and the 'civilizing' of the Rest of the World (see Said 2003), electricity had to captivate investors as a 'progressive investment' opportunity. Accounting for electricity during this phase of industrial development involved 'speculating' on possibilities for commercial success and scientific progress. Accounting's task was to establish the 'rhetorical fact' that electricity was cost effective and scientifically superior to oil-lamps and, hence, constituted a better commercial and industrial field both for investors to invest in and for the colonial state to support with necessary legislative measures. This speculative act of accounting was then performed by the electrical engineers in their trade magazines. Accounting was rhetorical, and individuals' social standing as 'scientists' and 'educated gentlemen' meant electrical engineers could perform such cost speculation and justification. 
During Egypt's postcolonial revolutionary politics, accounting gained a more explicit political role. Transformed from being separate arrangements in each company to a Uniform Accounting System across all nationalized economic enterprises, accounting became a political tool for signifying the unity of political power. Its role supplemented the military apparatuses of control and management. While strategic and operational decisions were taken on patrimonial connections and nationalist political logics of the military state, accounting through various legislative reforms evolved into an information system that helped produce macro-statistics, the primary function of which was to legitimize the militarized state politically. Accounting provided formality and legitimacy for patrimonial politics to appear bureaucratic. It was institutionalized as a system of codification and activity classification to align micro-organizational practices and outcomes with the central government's political parameters of reporting. This unification of accounting across state enterprises manifested coercive isomorphism through legislation (cf., DiMaggio and Powell 1983). Accounting was thus a system of transaction classification for political reporting rather than a tool for decision-making, monitoring, and control.

Accounting's political role during the neoliberal regime was paradoxical - simultaneously a reformation technology and a deficient institutional apparatus that hindered privatization. The World Bank-led privatization program made the politicized/militarized accounting regime's deficient and fraudulent nature publicly visible. Such accounting deficiencies, inter alia, made private investors deterred from purchasing the enterprise, failing the intended ownership transfer. However, the World Bank pushed on with neoliberal managerial reforms that institutionalized the neoliberal calculative logic of managing for profit within a state of public ownership. New ERP packages significantly helped institutionalize this neoliberal 'private mode' of managing a state-owned enterprise wherein elements of the institutional logic of capital accumulation (i.e., profits, revenue, and, especially, costs) became the key calculative elements in performance monitoring and control. Accounting was thus instrumental to this neoliberal managerial regime change (cf., Alawattage and Wickramasinghe 2008; Hoque and Hopper 1994; Uddin and Hopper 2001; Wickramasinghe et al. 2004). To complicate the paradoxical nature of the reforms outcome, EU-Egypt Association initiated 'budgetary reforms' then reintegrated this ERP-based 'private mode' of accounting into central government budgetary protocols to ensure the 'private mode of accounting' remained connected to the political state's institutional apparatuses and fiscal reporting. Within this institutional setting, 'a budgetary burden to the government' has registered in the minds of corporate managers as a strong managerial challenge to overcome. Thus, cost management has become the key strategic and operational theme.

Secondly, this institutionalization of profit-driven private management/accounting within state ownership and regulatory apparatuses manifests the nature of neoliberalism evolving in some peripheral countries. This is not remarkably different from popular critiques of neoliberalism that deem it a political doctrine for institutionalizing free market ideology and private property rights as the fundamental forces of economic development (Harvey 2005). However, the notion of market emerging here, and the resulting accountability regime, needs to be attended carefully. There is no free and competitive market here - only an ideology of free market, which is materialized through the institutionalized practices of costs and profit calculations and reporting. Competition is planned and structured through specific institutional arrangements for a stateowned holding company's subsidiary companies. These were specifically incorporated for this 
market structuring in a regulated environment whereby each subsidiary was granted near monopoly in different geographical areas (MEEDCO being one). No market-determined prices exist. Only a regulated pricing structure does, which has enabled a different mode of competition that is not market based but institutional - one enacted through a particular accounting mode (cf., Covaleski et al. 2003). The Unified Accounting System has supplemented ERP-based accounting for transaction processing and managerial decision-making to enable the holding company (and the government) to produce comparative statistics (i.e., league tables). Such tables put subsidiary companies into accounting-based competition based on cost performance (while confining their monopoly power geographically). EEHC's published annual reports do not meaningfully reveal its financial performance and position in a proto-typical sense. ${ }^{7}$ Instead, they contain various comparative statistics on electricity production, distribution, and costs of different geographical areas (i.e., each subsidiary company's geographical domains). EEHC annual reports are therefore competitive league tables of subsidiaries' operational statistics whereby statistics offers a 'sense of competition' between subsidiary companies. Subsidiary companies' management is driven by their aspirations of attaining a better position in these comparative statistics, "cost efficiency per Kilowatt hour of production" being the most critical statistic for corporate managers to judge how they outperform, or are outperformed by, other subsidiaries.

This competitive industrial structure is enacted through multi-agency accountability from numerous regulatory bodies (mainly the CAA, GACM, MEEE, and EEHC). As Munro (2012) argues, neoliberalism requires continual government intervention to transform microorganizational practices. In reinventing political interventions, the state transforms itself into interconnected regulatory bodies that infuse a 'sense of competition' among institutional actors. A "grand contradiction of neoliberalism was its passion for intervention in the name of nonintervention" (Miller 2010, 56), which hails the ideology of market competition as the natural basis for efficiency and effectiveness that would be, nevertheless, absent without heavy policing by regulatory bodies (i.e., the government appearing as non-government). This is neoliberal politics: politics appearing as non-politics so respondents often claim they are no longer being manipulated politically.

\subsection{Theoretical implications: colonial and neocolonial institutional dynamics}

Our empirical observations signified colonial and neocolonial politics whereby the political authority exercised a dominating top-down 'imposition' of institutional changes. First, we saw how colonial legislatures set up the electricity field as an element of colonial mercantile

\footnotetext{
7 Annual Reports of EEHC do not contain an income statement, statement of financial position, and a cash flow statement. In the last five annual reports the word profit was mentioned in only two instances. In the 2008/09 Annual Report (p.7) profit is mentioned as an element of corporate vision:
}

EEHC's main role is to coordinate, supervise, monitor and follow-up its affiliated companies
activities in the fields of generation, transmission and distribution of electric energy in order
to improve and develop the technical, operational and financial performance of the
companies to achieve the main goal of optimizing the use of all resources and maximizing the
profit.
reported in a summary table of 'Financial Situation of EEHC and its Affiliated Companies'. 
capitalism, then how the nationalist postcolonial state imposed centralized and militarized institutional apparatuses to pursue its political ideologies. This 'political imposition' continues in today's neoliberal era with a strong dictatorial centralized political state attempting to institutionalize economic ideologies and systems of private capital within public sector. Such continuance partially confirms DetM and other new institutional sociology (NIS) studies (e.g., Hopper and Major 2007; Oliver 1991; Scott 2001), which discuss the top-down institutionalization of political criteria through (re)inventing accounting and other managerial technologies and practices. The ability of the political elites for such imposition and legitimation stemmed from a subtle combination of militarist and constitutional coercion, on the one hand, and the consent manufactured through projecting such impositions as the institutional solutions for the politico-economic crises that the nation faces. Hence, management accounting change was a mean through which political elites in changing regimes enforced their will and legitimated their being in the power. However, our case study shows very little evidence for bottom-up agential processes translating this top-down imposition into recursive re-institutionalization. Such recursion is enabled in a rather restricted and structured manner by the regulatory framework, which means firms can collectively influence the regulatory tariff structure by showing how cost increments are driven by 'natural' market dynamics so are 'out of their control' - a paradoxical situation whereby political agency is enabled by demonstrating 'lack of agency' and, hence, inevitability.

This lack of 'social agency' to enact recursive institutionalization explicates a colonial political ontology, which 'the political' can explain. Following Laclau and Mouffe's (Laclau and Mouffe 1985; Mouffe 2005, 2013) differentiation between 'the political' and 'politics', we see no change in the ontologically fundamental antagonisms and contradictions. The power has always been centralized in a dictatorial political state attempting to dominate the economy and society through evolving institutional means (i.e., institutional politics). This means historical dialectics between ontologically fundamental social forces are instrumental in reproducing institutions (Hopper and Major 2007; Laclau and Mouffe 1985; Lecours 2000; Mouffe 2005, 2013; Skocpol 1995). Despite changes in the politics, we see a persistent colonial political ontology (i.e., state apparatuses reproducing 'colonial conditions' of domination). The salient feature of a colonial condition is the excessive centralization of political-economic power in state apparatuses, which limits possibilities for deliberative or agonistic social changes from the bottom (the social). The state is authoritative, dictatorial and imposing. The Egyptian state has never veered from this despite changing how this colonial imposition is institutionally realized. During the colonial era, the state dominated and mobilized colonial legislature to impose doctrines of colonial mercantile capitalism. The post-colonial military state was no different. It was equally or even more dictatorial than its predecessor in imposing nationalist political ambitions through political reforms. Neoliberal structural reforms seemed much more 'modern' but highly imposing and dominating. Neoliberal state is characterized by an institutional setting that provides a false image of deliberative governance with less political intervention. However, the subtle connection between these regulatory bodies - the central government (i.e., ministries) and global development funding bodies (e.g., EU and World Bank) - now constitutes the neoliberal political state. And this state is no different: it still imposes, leaving no social spaces for other 'social' actors (e.g., professionals, managers, trade unions) to enact their agency by forming recursive 
institutionalization and de-institutionalization. Even mega political events like the 'Arab Spring' could not change 'the political', but only the institutional 'politics'.

\section{References}

Alawattage, C., T. Hopper, and D. Wickramasinghe. 2007. Introduction to management accounting in less developed countries. Journal of Accounting and Organizational Change 3 (3):183-191.

Alawattage, C., and D. Wickramasinghe. 2008. Appearance of accounting in a political hegemony. Critical Perspectives on Accounting 19 (3):293-339. 2009. Institutionalisation of control and accounting for bonded labour in colonial plantations: a historical analysis. Critical Perspectives on Accounting 20 (6):701-715.

Annisette, M. 2004. The true nature of the World Bank. Critical Perspectives on Accounting 15 (3):303-323.

Arab Republic of Egypt. 2012. Circular preparing state's general budget FY2013/2014. Cairo: Ministry of Finance, Arab Republic of Egypt.

Ashraf, J., and S. Uddin. 2015. Military, 'managers' and hegemonies of management accounting controls: a critical realist interpretation. Management Accounting Research 29:13-26. . 2016. New public management, cost savings and regressive effects: a case from a less developed country. Critical Perspectives on Accounting 41:18-33.

Babb, S. 2005. The social consequences of structural adjustment: recent evidence and current debates. Annual Review of Sociology 31 (1):199-222.

Barley, S. R., and P. S. Tolbert. 1997. Institutionalization and structuration: studying the links between action and institution. Organization Studies 18 (1):93-117.

Boltanski, L., and L. Thévenot. 2006. On Justification: economies of worth: Princeton University Press.

Börner, T., and B. Verstegen. 2013. Change within institutional theory: towards a framework of coping with change. Journal of Accounting and Organizational Change 9 (3):304-321.

Bowman, A. 2015. An illusion of success: the consequences of British rail privatisation. Accounting Forum 39 (1):51-63.

Briston, R. J., and A. A. El-Ashker. 1984. The Egyptian accounting system: a case study in western influence. The International Journal of Accounting Education and Research 19 (2 (Spring)):129-155.

Burawoy, M. 1979. Manufacturing consent: changes in the labor process under monopoly capitalism. Chicago; London: University of Chicago Press.

. 1985. The politics of production: factory regimes under capitalism and socialism. London: Verso. 1998. The extended case method. Sociological Theory 16 (1):4-33.

2009. The extended case method: four countries, four decades, four great transformations, and one theoretical tradition: University of California Press.

Burns, J. 2000. The dynamics of accounting change: inter-play between new practices, routines, institutions, power and politics. Accounting, Auditing and Accountability Journal 13 (5):566596.

Burns, J., and R. W. Scapens. 2000. Conceptualizing management accounting change: an institutional framework. Management Accounting Research 11 (1):3-25.

Callon, M. 1986. Some elements of a sociology of translation: domestication of the scallops and fishermen of St. Brieuc Bay. In Power, action and belief: a new sociology of knowledge?, edited by J. Law. London: Routledge, 196-233.

Callon, M., and B. Latour. 1981. Unscrewing the big Leviathan: how actors macro-structure reality and how sociologists help them to do so. In Advances in social theory and methodology toward an integration of micro- and macro-sociologies, edited by K. Knorr-Cetina and A. V. Cicourel. Boston: Routledge \& Kegan Paul, 277-303.

Campbell, J. L. 1997. Recent trends in institutional political economy. International Journal of Sociology and Social Policy 17 (7/8):15-56. 
Clegg, S. 1989. Frameworks of power. London: Sage.

Cooke, B. 2004. The managing of the (third) world. Organization 11 (5):603-629.

Covaleski, M. A., M. W. Dirsmith, and S. Samuel. 2003. Changes in the institutional environment and the institutions of governance: extending the contributions of transaction cost economics within the management control literature. Accounting, Organizations and Society 28 (5):417-441.

Crompton, G., and R. Jupe. 2002. 'An awkward fence to cross': railway capitalization in Britain in the inter-war years. Accounting, Business and Financial History 12 (3):439 - 459. . 2003. "Such a silly scheme": the privatisation of Britain's railways 1992-2002. Critical Perspectives on Accounting 14 (6):617-645.

Dillard, J. F., J. T. Rigsby, and C. Goodman. 2004. The making and remaking of organization context: duality and the institutionalization process. Accounting, Auditing and Accountability Journal 17 (4):506-542.

DiMaggio, P. J., and W. W. Powell. 1983. The iron cage revisited: institutional isomorphism and collective rationality in organizational field American Sociological Review 48 (2):147-160.

Egyptian Stock Exchange. 2000. Accounting irregularities for companies listed on the Stock Exchange 1999/2000. Cairo: The Egyptian Stock Exchange.

Farah, N. R. 2009. Egypt's political economy: power relations in development. Cairo, Egypt: American University in Cairo Press.

Gardner, Z. 2007. Landscapes of power: the cultural and historical geographies of renewable energy in Britain since the 1870's, University of Nottingham, Nottingham.

Giddens, A. 1984. The constitution of society: outline of the theory of structuration. Cambridge: Polity.

Guerreiro, R., C. A. Pereira, and F. Frezatti. 2006. Evaluating management accounting change according to the institutional theory approach: a case study of a Brazilian bank. Journal of Accounting and Organizational Change 2 (3):196-228.

Harvey, D. 2005. A brief history of neoliberalism. Oxford: Oxford University Press.

Hopper, T., and M. Major. 2007. Extending institutional analysis through theoretical triangulation: regulation and activity-based costing in Portuguese Telecommunications. European Accounting Review 16 (1):59 - 97.

Hopper, T., M. Tsamenyi, S. Uddin, and D. Wickramasinghe. 2009. Management accounting in less developed countries: what is known and needs knowing. Accounting, Auditing and Accountability Journal 22 (3):469 - 514.

Hoque, A. K. M. Z. 1993. Management control in public sector enterprises: a case study of budgeting in the jute industry of Bangladesh, Thesis (Ph.D.), - University of Manchester, Deparment of Accounting and Finance., Manchester.

Hoque, Z., and T. Hopper. 1994. Rationality, accounting and politics: a case study of management control in a Bangladeshi jute mill. Management Accounting Research 5 (1):5-30.

How, S.-M., and C. Alawattage. 2012. Accounting decoupled: a case study of accounting regime change in a Malaysian company. Critical Perspectives on Accounting 23 (6):403-419.

Immergut, E. M. 1998. The theoretical core of the new institutionalism. Politics and Society 26 (1):5-34.

2006. Historical-institutionalism in political science and the problem of change. In Understanding Change: Models, Methodologies and Metaphors, edited by A. Wimmer and R. Kössler. London: Palgrave Macmillan UK, 237-259.

Issawi, C. 1961. Egypt since 1800: a study in lop-sided development. The Journal of Economic History 21 (1):1-25.

Jacobs, K. 2009. Beyond commercial in confidence: accounting for power privatisation in Victoria. Accounting, Auditing and Accountability Journal 22 (8):1258 - 1283.

Johansson, I.-L., and G. Baldvinsdottir. 2003. Accounting for trust: some empirical evidence. Management Accounting Research 14 (3):219-234. 
Jupe, R. 2009a. A "fresh start" or the "worst of all worlds"? a critical financial analysis of the performance and regulation of Network Rail in Britain's privatised railway system. Critical Perspectives on Accounting 20 (2):175-204.

2009b. New Labour, Network Rail and the third way. Accounting, Auditing and Accountability Journal 22 (5):709 - 735.

. 2012. The privatization of British energy: risk transfer and the state. Accounting,

Organizations and Society 37 (2):116-129.

Jupe, R., and G. Crompton. 2006. "A deficient performance": the regulation of the train operating companies in Britain's privatised railway system. Critical Perspectives on Accounting 17 (8):1035-1065.

Jupe, R., and W. Funnell. 2015. Neoliberalism, consultants and the privatisation of public policy formulation: the case of Britain's rail industry. Critical Perspectives on Accounting 29:65-85.

Kapur, D., J. P. Lewis, and R. Webb. 1997. The World Bank: its first half century. Washington, D.C.: Brookings Institution Press.

Keat, R. 1991. Introduction: starship Britain or universal enterprise? In Enterprise Culture, edited by R. Keat and N. Abercrombie. London: Routledge, 1-17.

Keat, R., and N. Abercrombie. 1991. Enterprise Culture: Routledge.

Laclau, E., and C. Mouffe. 1985. Hegemony and socialist strategy: towards a radical democratic politics. London: Verso.

Lassou, P. J. C., and T. Hopper. 2016. Government accounting reform in an ex-French African colony: the political economy of neocolonialism. Critical Perspectives on Accounting 36 (1):3957.

Latour, B. 1993. We have never been modern. New York; London: Harvester Wheatsheaf.

Lecours, A. 2000. Theorizing cultural identities: historical institutionalism as a challenge to the culturalists. Canadian Journal of Political Science 33 (3):499-522.

Macintosh, N. B., and T. Hopper. 2005. Accounting, the social and the political: classics, contemporary and beyond. Amsterdam; London: Elsevier.

McCartney, S., and J. Stittle. 2006. 'Not our problem': UK government's fiscal obligations towards the privatised railway network. Accounting Forum 30 (2):139-153.

2012. 'Engines of extravagance': the privatised British railway rolling stock industry. Critical Perspectives on Accounting 23 (2):153-167.

2015. Accounting for producer needs: the case of Britain's rail infrastructure. Accounting Forum 39 (2):109-120.

MEEDCO. 1998. Quarterly economic bulletin, MEEDCO. Cairo: MEEDCO. . 2013. Quarterly economic bulletin, MEEDCO. Cairo: MEEDCO.

Meyer, J. W., and B. Rowan. 1977. Institutionalized organizations: formal structure as myth and ceremony. American Journal of Sociology 83 (2):340-363.

Miller, P., and N. Rose. 1990. Governing economic life. Economy and Society 19 (1):1 - 31.

Miller, T. 2010. Michel Foucault: the birth of biopolitics: lectures at the Collège de France, 197879. International Journal of Cultural Policy 16 (1):56-57.

Mouffe, C. 2005. On the political: Abingdon; Routledge. 2013. Agonistics: thinking the world politically. London: Verso.

Munro, I. 2012. The Management of circulations: biopolitical variations after Foucault. International Journal of Management Reviews 14 (3):345-362.

Neu, D., and E. O. Gomez. 2006. The ethics of World Bank lending. Accounting Forum 30 (1):119.

Neu, D., E. Ocampo Gomez, C. Graham, and M. Heincke. 2006. "Informing" technologies and the World Bank. Accounting, Organizations and Society 31 (7):635-662.

Neu, D., E. Ocampo Gomez, O. G. Ponce de Leon, and M. Flores Zepeda. 2002. Facilitating globalization processes: financial technologies and the World Bank. Accounting Forum 26 (3\&4):271-290. 
Ogden, S. G. 1995. Transforming frameworks of accountability: the case of water privatization. Accounting, Organizations and Society 20 (2-3):193-218.

1997. Accounting for organizational performance: the construction of the customer in the privatized water industry. Accounting, Organizations and Society 22 (6):529-556.

Oliver, C. 1991. Strategic responses to institutional processes. The Academy of Management Review $16(1): 145-179$.

Omran, M. 2004. Performance consequences of privatizing Egyptian state-owned enterprises: the effect of post-privatization wwnership structure on firm performance. Multinational Finance Journal 8 (1/2):73-114.

Osman, T. 2013. Egypt on the brink: from Nasser to the Muslim brotherhood: Yale University Press.

Robins, N. 2006. The corporation that changed the world: how the East India Company shaped the modern multinational. London: Pluto Press.

Robinson, M., and D. Last. 2009. A basic model of performance-based budgeting. In Technical Notes and Manuals: International Monetary Fund - Fiscal Affairs Department

Said, E. W. 2003. Orientalism. London: Penguin.

Saravanamuthu, K. 2004. What is measured counts: harmonized corporate reporting and sustainable economic development. Critical Perspectives on Accounting 15 (3):295-302.

Scott, W. R. 2001. Institutions and organizations. 2nd ed. Thousand Oaks, Calif.; London: Sage.

Shaoul, J. 1997. The power of accounting: reflecting on water privatization? Accounting, Auditing and Accountability Journal 10 (3).

Sharma, U., and S. Lawrence. 2005. Public sector reform, global trends vs. local needs: the case of a state rental organisation in Fiji. Journal of Accounting and Organizational Change 1 (2). . 2015. Power, politics and privatization: a tale of a telecommunications company. Critical Perspectives on Accounting 28:13-29.

Skaerbaek, P., and P. Melander. 2004. The politics of the changing forms of accounting: a field study of strategy translation in a Danish government-owned company under privatisation. Accounting, Auditing and Accountability Journal 17 (1):17-40.

Skocpol, T. 1995. Why I am an historical institutionalist. Polity 28 (1):103-106.

Soliman, S. 1999. State and industrial capitalists in Egypt. In Cairo Papers. Cairo, Egypt: American University in Cairo Press, 1-101.

Sullivan, D. J. 1990. The political economy of reform in Egypt. International Journal of Middle East Studies 22 (3):317-334.

Thornton, P. H., and W. Ocasio. 2008. Institutional logics. In The SAGE handbook of organizational institutionalism, edited by R. Greenwood, C. Oliver, R. Suddaby and K. Sahlin. Los Angeles ; London: SAGE, 99-129.

Thornton, P. H., W. Ocasio, and M. Lounsbury. 2012. The institutional logics perspective: a new approach to culture, structure and process. Oxford: Oxford University Press.

Tolbert, P. S., and L. G. Zucker. 1983. Institutional sources of change in the formal structure of organizations: the diffusion of civil service reform, 1880-1935. Administrative Science Quarterly 28 (1):22-39.

Uddin, S. 1997. The role of management control systems in privatisation: a labour process analysis of a Bangladeshi case study. PhD Thesis, Accounting and Finance, University of Manchester, Manchester.

Uddin, S., and T. Hopper. 2001. A Bangladesh soap opera: privatisation, accounting, and regimes of control in a less developed country. Accounting, Organizations and Society 26 (7-8):643672.

. 2003. Accounting for privatisation in Bangladesh: testing World Bank claims. Critical Perspectives on Accounting 14 (7):739-774.

Weber, M. 1958. The protestant ethic and the spirit of capitalism. New York: Charles Scribner's Sons. . 1968. Economy and society: an outline of interpretive sociology: New York: Bedminster Press. 
Westley, J. R. 1998. Change in the Egyptian economy: 1977 - 1997. Cairo Papers in Social Science 21 (3):18-41.

Wickramasinghe, D., T. Hopper, and C. Rathnasiri. 2004. Japanese cost management meets Sri Lankan politics: disappearance and reappearance of bureaucratic management controls in a privatised utility. Accounting, Auditing and Accountability Journal 17 (1):85-120.

Wickramasinghe, D. P. 1996. "Rationales" of accounting control and ownership change in a development context: a mode of production theory analysis of two Sri Lankan case studies, Thesis (Ph.D.) - University of Manchester, 1996., Manchester.

Youssef, S. M. 1996. Structural reform programme of Egyptian state-owned enterprises current impact and future prospects. The Journal of Management Development 15 (5):88-99.

Zald, M. N. 2000. Ideologically Structured Action: An Enlarged Agenda for Social Movement Research. Mobilization: An International Quarterly 5 (1):1-16.

Zohny, A. Y. 1988. The politics, economics, and dynamics of development administration in contemporary Egypt: an interdisciplinary approach: Schriesheim-Heidelberg, West Germany. 